\title{
Enhancement of Lactase Activity in Milk by Reactive Sulfhydryl Groups Induced by Heat Treatment
}

\author{
J. Jiménez-Guzmán, ${ }^{*}$ A. E. Cruz-Guerrero, ${ }^{*}$ G. Rodríguez-Serrano, ${ }^{*}$ \\ A. López-Munguía, $†$ L Gómez-Ruiz, * and M García-Garibay* \\ *Departamento de Biotecnología, \\ Universidad Autónoma Metropolitana, Iztapalapa, A.P. 55-535, \\ Mexico City D.F., 09340 Mexico. \\ †Instituto de Biotecnología, Universidad Nacional Autónoma de México, \\ A.P. 510-3, Cuernavaca, Mor., 62271, México
}

\begin{abstract}
The effects of heat treatments of milk and whey prior to lactose hydrolysis with Kluyveromyces lactis $\beta$-galactosidase were studied. It was observed that heat treatment of milk significantly increases lactase activity, with a maximum activity increase found when milk was heated at $55^{\circ} \mathrm{C}$. In whey from 55 up to $75^{\circ} \mathrm{C}, \beta$ galactosidase activity decreased slightly. Nevertheless, heating whey at $85^{\circ} \mathrm{C}$ for $30 \mathrm{~min}$ raised the rate of hydrolysis significantly. Electrophoretic patterns and UV spectra proved that the activity change correlated with milk protein denaturation, particularly that of $\beta$ lactoglobulin. Heating whey permeate did not increase the enzyme activity as heating whole whey; but heating whey prior to ultrafiltration also resulted in enzyme activation. Measurement of free sulfhydryl (SH) groups in both whey and heated whey permeate showed that the liberation of free $\mathrm{SH}$ is highly correlated to the change of the activity. Furthermore, this activation can be reversed by oxidizing the reactive sulfhydryl groups, proving that the observed effect may be related to the release of free $\mathrm{SH}$ to the medium, rather than to the denaturation of a thermolabile protein inhibitor.
\end{abstract}

(Key words: ( $\beta$-galactosidase, lactase, sulfhydryl groups, whey protein).

Abbreviation key: ONP = ortho-nitro-phenol, ONPG $=$ ortho-nitro-phenyl- $\beta$-D-galactoside, $\mathbf{R f}=$ migration coefficient, $\mathbf{S H}=$ sulfhydryl, $\nu_{\mathbf{0}}=$ hydrolysis rate .

\section{INTRODUCTION}

In the dairy industry, milk is commonly heated for a wide variety of purposes. Depending on the heating temperature, this procedure may cause several changes

Received November 1, 2001.

Accepted April 25, 2002

Corresponding Author: Dr. Mariano García-Garibay; e-mail: jmgg@xanum.uam.mx. in milk such as salt precipitation due to the formation of insoluble complexes (Fox and McSweeney, 1998), protein denaturation, and interactions among milk components (Hillier and Lyster, 1979; Dagleish, 1990; Morgan et al., 1998). The physical and chemical changes produced upon heating of milk may affect other processes carried out in milk.

Van Dam et al. (1950) suggested that heat treatment of milk previous to lactose hydrolysis with lactase could increase the rate of reaction. Sfortunato and Connors (1958) reported that Saccharomyces fragilis (Kluyveromyces marxianus) lactase yield rate increase was higher in pasteurized milk when compared with sterilized milk. Ever since, little research has been carried out to explain this phenomenon, although additional authors have reported the same type of observations in heated milk or whey (Wendorff et al., 1970; 1971; Guy and Bingham, 1978; Greenberg and Mahoney, 1984; Greenberg et al., 1985), others have not observed such effect (Kosikowski and Wierzbicki, 1973; Mahoney and Adamchuk, 1980).

Wendorff et al. (1970; 1971) reported that lactase activity was higher in heat-treated milk or whey when compared with a control prepared treating a buffer solution. Greenberg et al. (1985) and Mahoney and Adamchuk (1980) observed that there was no effect on the enzyme activity when heating milk, however, a rate increase was detected when acting on heated whey. Other unsuccessful experiments include heating buffer solutions containing lactose where no increase of activity was found (Wendorff et al., 1970; Mahoney and Adamchuk, 1980).

Recently, Mahoney (1997) pointed out that this situation remains unresolved and among several speculations explained the effect as the consequence of the presence of a thermolabile lactase inhibitor, and/or the thermal denaturation of milk proteins.

The aim of this work was to evaluate the effect of thermal treatments of milk on $\beta$-galactosidase (EC 3.2.1.23) activity, and to correlate physical or chemical changes on milk components with the observed effect. 


\section{MATERIALS AND METHODS}

\section{Substrates}

Raw milk was obtained from a local farm near Mexico City. Whey was prepared by clotting raw milk with commercial microbial rennet (Cuamex, Mexico City). The curd was cut and allowed to drain. The whey was filtered through a cotton layer, and then centrifuged at 10,000 rpm for 20 min using a Beckman J2-MI centrifuge (Beckman Instruments, Palo Alto, CA). Ultrafiltrated whey permeate was prepared by means of a tangential bench Minitan Acrylic Ultrafilter System with 10,000 nominal molecular weight limit cellulose plates (Millipore, Bedford, MA).

\section{Treatments}

Samples of $100 \mathrm{ml}$ of milk, whey, UF whey permeate, and solutions of $\alpha$-lactalbumin ( $1 \mathrm{mg} / \mathrm{ml}), \beta$-lactoglobulin $(3 \mathrm{mg} / \mathrm{ml})$, and bovine serum albumin $(0.3 \mathrm{mg} / \mathrm{ml})$ (proteins from Sigma Chemical Co, St. Louis, MO) were treated at either $55,65,75$, or $85^{\circ} \mathrm{C}$ for $30 \mathrm{~min}$; controls for each substrate were not subjected to any heat treatment. All pure protein solutions were prepared in a phosphate buffer $0.05 M \mathrm{pH} \mathrm{6.6,} \mathrm{and} \mathrm{no} \mathrm{lactose} \mathrm{was}$ added before or after the proteins were heated. The samples were heated by immersion of $250 \mathrm{ml}$ flasks in a water bath with the required temperature; they were allowed to reach the treatment temperature at which they were held for $30 \mathrm{~min}$, after which they were cooled by running tap water and storage at $4^{\circ} \mathrm{C}$. Commercial $\mathrm{H}_{2} \mathrm{O}_{2}$ was used at an equimolar ratio to oxidize free sulfhydryls (SH) in whey permeate.

\section{Enzyme Activity}

Maxilact LX-5000 (Gist Brocades, Delft, The Netherlands) was used as a source of $\beta$-galactosidase. Lactose was hydrolysed with a proper dilution of the enzyme


the enzyme activity measured following the increase in glucose in the reaction medium during the first $9 \mathrm{~min}$ sampling each $3 \mathrm{~min}$. The reaction was stopped in each sample by mixing it with the same volume of $12 \%$ TCA solution (J.T. Baker, Xalostoc, Mexico); this treatment precipitated all proteins, resulting in a clear solution in which glucose was determined with a glucose enzymatic determining kit (Spinreact, S.A., Olot, Spain). In other cases, $0.034 M$ ortho-nitro-phenyl- $\beta$-D-galactoside (ONPG, Sigma Chemical Co.) was used as substrate. In this case, the enzyme activity was measured following the release of ortho-nitro-phenol (ONP) to the medium. The hydrolysis rate $\left(\nu_{0}\right)$ was calculated from the

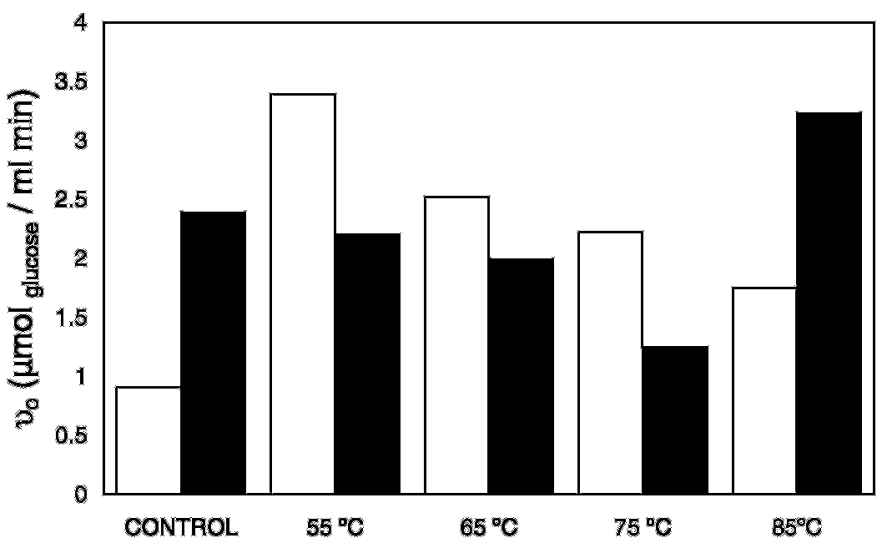

Figure 1. Effect of heat treatment of milk ( $\square$ ) and whey ( $\square$ ) on lactose hydrolysis rate $\left(\nu_{0}\right)$.

linear portion of data of either glucose or ONP production vs. time.

\section{Analyses}

Sulfhydryl groups were determined using Ellman's reaction as described by Patrick and Swaisgood (1976). Ellman's reagent was from Sigma Chemical Co.

Nondenaturing electrophoretic patterns were obtained using acrilamide/bisacrilamide gels prepared at several proportions of acrilamide/bisacrilamide $(\mathrm{T}=5$, $7,9,10,12.5$ and 15\%). Electrophoresis were run at 200 volts in a mini-Protean II cell electrophoresis chamber using a Power/Pac 300 as a power supply (equipment and reagents from Bio Rad, Hercules, CA).

UV spectra were obtained using a Shimadzu UV 160 A spectrophotometer (Shimadzu, Japan).

\section{Statistical Analyses}

Each experiment was performed three times. Data were analysed with a variance test, and in some cases a Tukey test or a t-student test was performed using the Statistical Analysis System software (SAS Institute, Cary, NC). Pearson Correlation coefficients were calculated with the same software.

\section{RESULTS AND DISCUSSION}

\section{Effect of Heat Treatment}

Milk subjected to the various heat treatments showed significantly higher hydrolysis rates than those found in the control (Figure 1). The hydrolysis rate observed when milk was heated at $55^{\circ} \mathrm{C}$ was three times higher than that of the control $(\alpha=0.0001)$. In milk treated at higher temperatures $\left(65\right.$ and $\left.85^{\circ} \mathrm{C}\right)$, the rate was also 


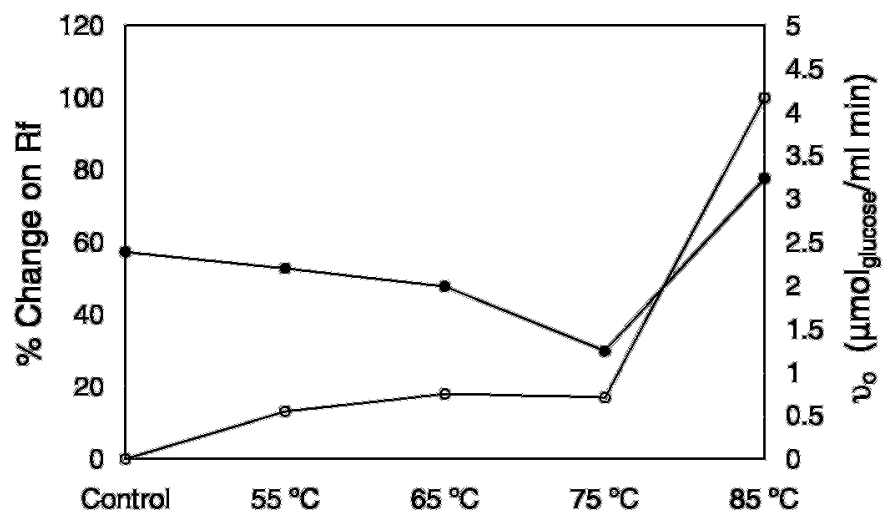

Figure 2. Effect of heat treatment of whey on change of migration coefficient (Rf) of $\beta$-lactoglobulin $(O)$ and its relationship with lactose hydrolysis rate $\left(\nu_{0}\right)(\bullet)$.

higher than the control $(\alpha=0.0001)$; nevertheless, after the maximum observed at $55^{\circ} \mathrm{C}$, it decreased as the temperature increased.

When whey was subjected to the same treatments (Figure 1), the hydrolysis rate decreased with increasing temperature, particularly at $75^{\circ} \mathrm{C}$, but at $85^{\circ} \mathrm{C}$ a dramatic activation effect was observed with an enzyme activity $35.4 \%$ higher than the control $(\alpha=0.0503)$.

\section{Effect of Whey Protein Denaturation}

The change in activity observed in whey may be due to protein unfolding or denaturation, since the change on enzyme activity observed in heated whey (Figure 1) shows a similar pattern to that reported for whey protein denaturation by Parnell-Clunies et al. (1988) and Parris et al. (1991). It has been reported that the first step in whey protein denaturation starts at temperatures between 61 and $67^{\circ} \mathrm{C}$ and that the degree of denaturation increases with increasing the temperature (Parris et al., 1991). Therefore, whey protein denaturation was studied and correlated with the kinetic results.

Nondenaturing gel electrophoresis was used to follow the denaturation of whey proteins subjected to the different heat treatments as already described. The migration coefficient (Rf) of some proteins changed significantly as the temperature increased, particularly those of bovine serum albumin (data not shown) and $\beta$-lactoglobulin (Figure 2), which has been reported as the most thermolabile protein in whey (Fox and McSweeney, 1998) showing that these proteins undergo a partial heat-denaturation. Figure 2 suggests that protein denaturation could have an effect on enzyme activity, particularly at $85^{\circ} \mathrm{C}$, when the protein was fully denatured.

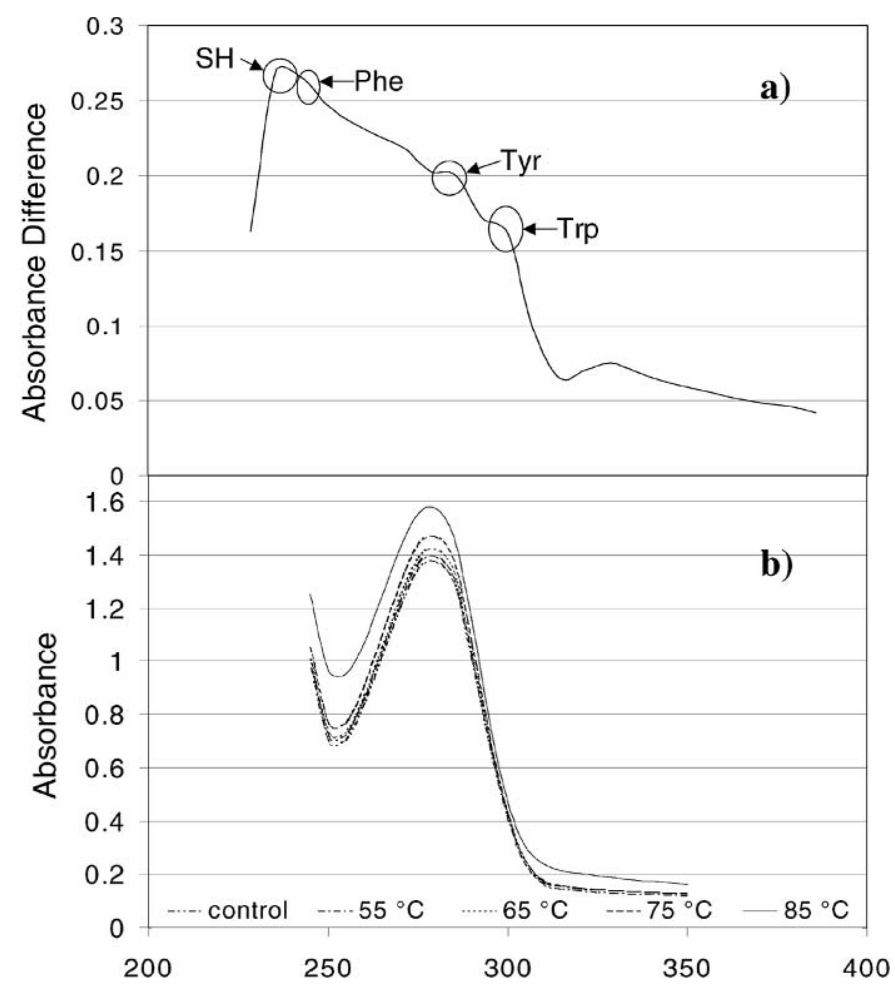

Figure 3. Effect of heat treatment on the denaturation of $\beta$-lactoglobulin a) Differential spectrum of $\beta$-lactoglobulin heated at $85^{\circ} \mathrm{C}$ with respect to non-heated $\beta$-lactoglobulin. Circles show maximum absorbance wavelength of particular aminoacids. b) Absorbance spectra of $\beta$-lactoglobulin after different heat treatments.

Since $\alpha$-lactalbumin, $\beta$-lactoglobulin and bovine serum albumin are the most abundant whey proteins, experiments were carried out with solutions of the pure proteins heated at the same temperatures as milk and whey in order to follow the changes in their UV spectra. Only the UV spectrum of $\beta$-lactoglobulin was considerably modified with heating (Figure 3 ); furthermore, the greatest change was observed at a wavelength of around $252 \mathrm{~nm}$ corresponding to the absorbance wavelength of SH groups (Figure 3a). These results suggest that the conformational changes of $\beta$-lactoglobulin resulted in free sulfhydryl groups (SH) exposure, as it had already been reported by several authors for the first stages of $\beta$-lactoglobulin heating (Taylor and Richardson, 1979; Parnell-Clunies et al., 1988; Iametti et al., 1995; 1996; Prabakaran and Damodaran, 1997). According to the spectra shown in Figure $3 \mathrm{~b}$, the highest degree of denaturation occurred at $85^{\circ} \mathrm{C}$, temperature at which the highest activation of lactase in whey was observed (Figure 1).

$\beta$-Lactoglobulin denaturation degree was related to the percent of change of its Rf, and was compared to the change on enzyme activity (Figure 2). These results show that denaturation and/or precipitation of some 


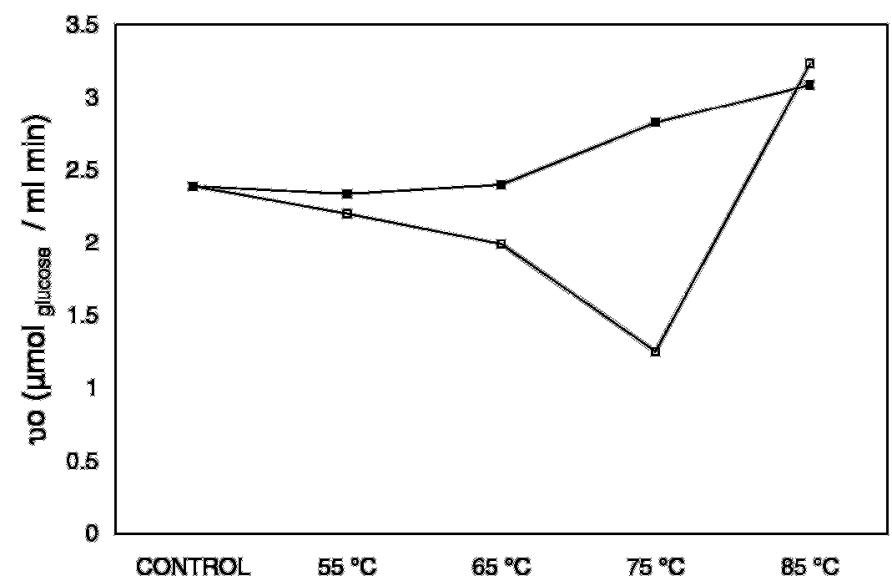

Figure 4. Comparison of hydrolysis rate $\left(\nu_{0}\right)$ in whey $(\square)$ and whey permeate heated before ultrafiltration (preheated whey permeate)

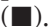

of the whey proteins may be related to the change of lactase activity $(r=0.79)$, suggesting that denatured proteins, at least $\beta$-lactoglobulin, could influence the observed effect.

In order to determine whether the activating effect was due to a change in the protein itself or the release of small molecular weight compounds, activity was measured in ultrafiltrated whey permeate. Whey ultrafiltration permeate does not contain protein. When the whey permeate was heat-treated, no statistically significant changes were observed (data not shown), and the values of $\nu_{0}$ obtained when whey permeate was heated did not differ from those obtained in unheated whey or preheated whey permeate. On the other hand, when whey was heated prior to ultrafiltration (in the presence of the proteins) the activity measured in the permeate increased with increasing temperature (Figure 4), suggesting that the activating effect is produced by a low molecular weight compound released to the medium after heat treatment of milk proteins.

\section{Effect of Reactive Sulfhydryl Groups on Lactase Activity}

The production of small molecular weight sulphurcontaining compounds such as $\mathrm{H}_{2} \mathrm{~S}$ or $\mathrm{H}_{3} \mathrm{C}-\mathrm{S}-\mathrm{CH}_{3}$ has been reported in milk due to heat treatment even at temperatures below protein denaturation point if the holding time is long enough (Lewis, 1994), as it was done in this work. These compounds would be produced from denatured whey protein obtained as a result of the thermal treatments (Lewis, 1994; Fox and Mc Sweeney, 1998). Such compounds could cross the ultrafiltration membrane and appear in the permeate. It is also known that reactive sulfhydryl groups increase lactase activity

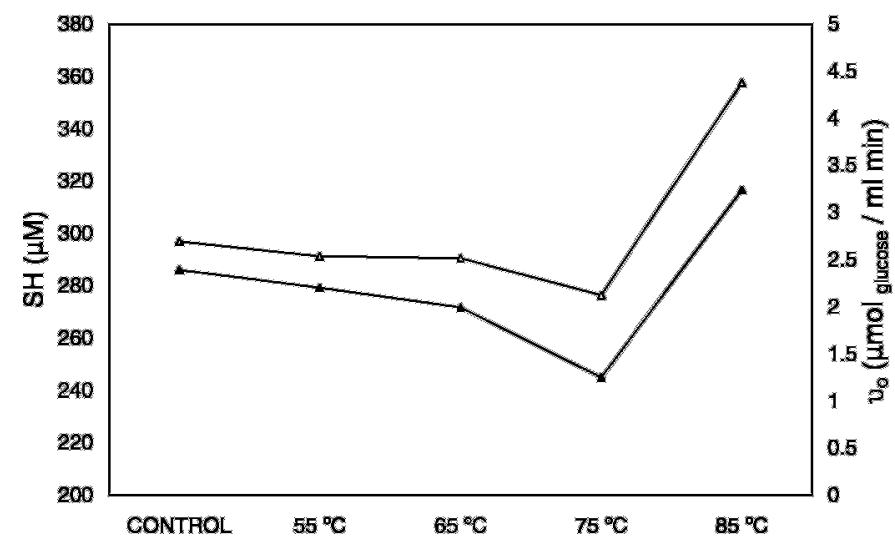

Figure 5. Relationship between $\mathrm{SH}$ groups released by heat treatment of whey $(\triangle)$ and lactose hydrolysis rate $\left(\nu_{0}\right)(\boldsymbol{\Delta})$. SH groups were measured by Ellman's reaction.

in buffer solutions, as was observed in our laboratory (data not shown). Considering that the UV spectra of $\beta$-lactoglobulin showed a considerable increase in absorbance at the wavelength at which sulfhydryls absorb, the change on their concentration was followed on samples of heat-treated whey.

Reactive sulfhydryls decreased slightly when whey was treated at 55 to $75^{\circ} \mathrm{C}$, but when the treatment took place at $85^{\circ} \mathrm{C}$ their concentration increased significantly; this may be due to the fact that at $85^{\circ} \mathrm{C}$, the protein is completely denatured displaying all its reactive groups: both denaturation and $\mathrm{SH}$ exposure at $85^{\circ} \mathrm{C}$ can be observed in Figures 2 and 3, respectively. As reported by Dalgleish (1990), denaturation of whey proteins is a complex process: disulfide-linked aggregates are formed between serum proteins themselves at first denaturation stages, as has also been reported by Iametti et al. (1996). Recent reports establish that this reaction may take place even at room temperature, but its extent increases with increasing temperature (Apenten and Galani, 2000). This interaction could explain the reduction of $\mathrm{SH}$ groups when the whey is heated at the lowest temperatures; while at the highest temperature $\left(85^{\circ} \mathrm{C}\right)$ the complete denaturation of whey proteins leads to an increase of reactive sulfhydryl groups possibly by releasing them as part of small molecules (Patrick and Swaisgood, 1976; Lewis, 1994; Carbonaro et al., 1997; Fox and Mc Sweeney, 1998).

The change in $\beta$-galactosidase activity in whey is clearly correlated with the change on $\mathrm{SH}$ measured in treated whey with a high correlation coefficient $(\mathrm{r}=$ 0.92), suggesting an effect of the exposure of sulfhydryl groups from the whey proteins on the enzyme molecule (Figure 5). Measurement of sulfhydryls in the preheated whey permeate also showed that they correlate highly with the change of the activity $(r=0.86)$. Even 
more, when the sulfhydryls in the permeate were oxidized with $\mathrm{H}_{2} \mathrm{O}_{2}$ the activating effect disappeared (data not shown), suggesting that they participate in the activation of the enzyme.

The possibility that the effect on the enzyme is due to a nonproteic thermolabile inhibitor as suggested by Mahoney (1997), is very unlikely since heating whey permeate after ultrafiltration did not increase the enzyme activity as heating whey. Additionally, the activating effect found when whey was heated prior to ultrafiltration was reversed by oxidizing reactive sulfhydryls demonstrating that these are responsible for the effect.

When comparing the activity patterns obtained in whey and preheated whey permeate (Figure 4), there is no significant observable difference between them after heating at $85^{\circ} \mathrm{C}$. This demonstrates that the release of reactive sulfhydryls as low molecular weight compounds is responsible for the activating effect. Nevertheless, at $75^{\circ} \mathrm{C}$ there is a significant difference between activity observed in whey and preheated whey permeate, suggesting that besides the activating effect of sulfhydryls, additional effects are produced by whey proteins or their denaturation products.

The enzyme levels used to measure activity in milk and whey were exactly the same, nevertheless, these two systems are different from each other and undergo very different reactions either without heating or when subjected to the same heat treatment. Reactivity of $\mathrm{SH}$ groups, and the resulting redox potential, in the two systems (milk and whey) are different. While in raw milk, the concentration of reactive sulfhydryl groups is either absent or very low (Taylor and Richardson, 1980) due to the association of whey proteins with caseins or among themselves through disulfide interchanges (Patrick and Swaisgood, 1976; Taylor and Richardson, 1980), in whey, proteins can be found as monomers which expose their reactive SH groups more easily. Heating milk increases its antioxidant activity, with a corresponding decrease in the redox potential (Taylor and Richardson, 1980); this itself could also help to increase lactase activity: it has been reported that $K$. lactis lactase has one $\mathrm{SH}$ in its active site, which could participate in the binding of lactose to the enzyme prior to its hydrolysis (Whitaker, 1994). In that way a reducing environment could increase sulfhydryl reactivity thus helping to increase lactase activity; nevertheless, if this were the only cause of the effect on the activity rate, it would tend to increase constantly with the increasing temperature, instead of decreasing at temperatures above $65^{\circ} \mathrm{C}$.

The fact that there was a maximum activity when milk was preheated between 55 and $65^{\circ} \mathrm{C}$ may be explained by the increase on the exposure of reactive sulf- hydryl groups (SH) from milk proteins (Elfgam and Weelock, 1978; Parnell-Clunies et al., 1988; Shimada and Cheftel, 1989; Lewis, 1994; Iametti et al., 1996; Carbonaro et al., 1996; 1997; Apenten and Galani, 1999; 2000). The change in the redox potential causes an increase in the reactivity of sulfhydryls in $\kappa$-casein, $\alpha_{\mathrm{s} 2}$-casein, and $\beta$-lactoglobulin (Taylor and Richardson, 1980; Apenten and Galami, 1999), which have been reported as "slowly reactive" in raw milk. Furthermore, it has been demonstrated that with low heat treatments, the reactive sulfhydryl groups increase, and upon heating above whey protein denaturation temperatures (around $61^{\circ} \mathrm{C}$ ) $\mathrm{SH}$ group concentration in milk decreases owing to SH-disulphide exchange between different proteins (Patrick and Swaisgood, 1976; Parnell-Clunies et al., 1988). Haque and Kinsella (1988) and Haque et al. (1987) reported that heat treatment of milk at high temperatures induces a reaction between $\beta$-lactoglobulin's reactive $\mathrm{SH}$ and $\kappa$-casein, resulting in changes in the concentration of reactive $\mathrm{SH}$. Parnell-Clunies et al. (1988) have already observed the effect of heat treatment in milk at different temperatures, finding a decrease in reactive $\mathrm{SH}$ when milk is treated above $65^{\circ} \mathrm{C}$. Dalgleish (1990) also reported that aggregates are formed between casein micelles and denatured whey proteins; denatured serum proteins are rapidly and efficiently aggregated, either with themselves or with $\kappa$-casein. According to Dalgleish (1990), heating milk above $70^{\circ} \mathrm{C}$ results in a decrease in the amount of reactive $\mathrm{SH}$ due to the already mentioned protein interactions, aggregation rate being higher as the temperature increases. The lactase activity profile along the different milk treatment temperatures (Figure 1) is very similar to the change on reactive sulfhydryl groups reported by Parnell-Clunies et al. (1988). These authors observed that as milk treatment temperature increases, the reactive sulfhydryl groups decrease, due to reaction between $\kappa$-casein and $\beta$-lactoglobulin. This suggests that the effect on the enzyme activity could be related to the change on reactive sulfhydryl groups concentration in milk, which was also demonstrated here in the case of whey, where the pattern of SH groups release is different than in milk, due to different protein-protein interactions.

The reasons why other authors did not find effects of heat treatment of milk on lactase activity are possibly due to the different techniques used in the lactase activity assay. Kosikowski and Wierzbicki (1973) measured lactose hydrolysis after $48 \mathrm{~h}$ of incubation with lactase, but did not report initial reaction rates. Greenberg et al. (1985) and Mahoney and Adamchuk (1980) did not find an effect on milk heated at either 63 or $85^{\circ} \mathrm{C}$, while in whey they found a marked increase in lactase activity particularly at $85^{\circ} \mathrm{C}$. The reason why these authors did 
not find a difference in milk is unclear, especially since the heat treatment effect has been demonstrated here as well as by Sfortunato and Connors (1958), Van Dam et al. (1950), and Wendorff et al. (1970; 1971).

\section{CONCLUSION}

Heat treatment of milk and whey previous to lactose hydrolysis increased enzyme activity; the hydrolysis rate change is highly correlated with the liberation of sulfhydryl groups from whey proteins. The possibility of a thermolabile lactase inhibitor is quite unlikely; as was demonstrated using UF whey permeate. Sulfhydryl exposure due to heat treatment follows different patterns in milk and whey due to protein interactions, which leads to different $\beta$-galactosidase activation profiles in both media.

\section{REFERENCES}

Apenten, R. K. O., and D. Galani. 1999. Is the rate of sulphur-disulfide exchange between the native $\beta$-lactoglobulin and PDS related to protein conformational stability? Int. J. Food Sci. Technol. $34: 483-486$

Apenten, R. K. O., and D. Galani. 2000. Protein Stability function relations: native $\beta$-lactoglobulin sulfhydryl-disulphide exchange with PDS. J. Sci. Food Agric. 80:447-452.

Carbonaro, M., F. Bonomi, S. Iametti, and E. Carnovale. 1996. Modifications in disulfide reactivity of milk induced by different pasteurization conditions. J. Food Sci. 61:495-499,509.

Carbonaro, M., M. Cappelloni, S. Sabbadini, and E. Carnovale. 1997. Disulfide reactivity and in vitro protein digestibility of different thermal-treated milk samples and whey proteins. J. Agric. Food Chem. 45:95-100.

Dalgleish, D. G. 1990. Denaturation and aggregation of serum proteins and caseins in heated milk. J. Agric. Food Chem. 38:1995-1999.

Elfagm, A., and J. Wheelock. 1978. Heat interaction between $\alpha$-lactalbumin, $\beta$-lactoglobulin and casein in bovine milk. J. Dairy Sci. 61:159-163.

Fox, P. F., and P. L. H. McSweeney. 1998. Dairy Chemistry and Biochemistry, Blackie Academic and Professional, London.

Galani, D., and R. K. O. Apenten. 1999. Heat induced denaturation and aggregation of $\beta$-lactoglobulin: Kinetics of formation of hydrophobic and disulphide-linked aggregates. Int. J. Food Sci. Technol. 34:467-476.

Greenberg, N. A., and R. R. Mahoney. 1984. The activity of lactase (Streptococcus thermophilus) in milk and sweet whey. Food Chem. 15:307-313.

Greenberg, N. A., T. Wilder, and R. R. Mahoney. 1985. Studies on the thermostability of lactase (Streptococcus thermophilus) in milk and sweet whey. J. Dairy Res. 52:439-449.

Guy, E. J., and E. W. Bingham. 1978. Properties of $\beta$-galactosidases of Saccharomyces lactis in milk and milk products. J. Dairy Sci. 61:147-151.

Haque, Z., and J. E. Kinsella. 1988. Interaction between heated $\kappa$ casein and $\beta$-lactoglobulin. Predominance of hydrophobic interac- tions in the initial stages of complex formation. J. Dairy Res. 55:67-80.

Haque, Z., M. M. Kristjansson, and J. E. Kinsella. 1987. Interaction between $\kappa$-casein and $\beta$-lactoglobulin: possible mechanism. J. Agric. Food Chem. 35:644-649.

Hillier R. M., and R. L. J. Lyster. 1979. Whey protein denaturation in heated milk and cheese whey. J. Dairy Res. 46:95-102.

Iametti, S., S. Cairoli, B. De Gregori, and F. Bonomi. 1995. Modifications of high order structures upon heating of $\beta$-lactoglobulin: dependence on protein concentration. J. Agric. Food Chem. 43:53-58.

Iametti, S., B. De Gregori, G. Vecchio, and F. Bonomi. 1996. Modifications occur at different structural levels during the heat denaturation of $\beta$-lactoglobulin. Eur. J. Biochem. 237:106-112.

Kosikowski, F. V., and L. E. Wierzbicki, 1973. Lactose hydrolysis of raw and pasteurized milks by Saccharomyces lactis lactase. J. Dairy Sci. 56:146-148.

Lewis, M. J. 1994. Heat Treatment of Milk. Pages 45-50 in Modern Dairy Technology. Vol. 1. Advances in Milk Processing. R. K. Robinson, ed. Chapman and Hall, 2nd edition, London.

Mahoney, R. R. 1997. Lactose: Enzymatic modification. Page 95 in Advanced Dairy Chemistry Volume 3. P. F. Fox, ed. Chapman \& Hall, London.

Mahoney, R. R., and C. Adamchuk. 1980. Effect of milk constituents on the hydrolysis of lactose by lactase from Kluyveromyces fragilis. J. Food Sci. 45:962-964, 968.

Morgan, F., S. Bouhallab, G. Mollé, G. Henry, J. L. Maubois, and J. Léonil. 1998. Lactolation of $\beta$-lactoglobulin monitored by electrospray ionisation mass spectrometry. Int. Dairy J. 8:95-98.

Parnell-Clunies, E., Y. Kakuda, D. Irvine, and K. Mullen. 1988. Heatinduced protein changes in milk processed by vat and continuous heating systems. J. Dairy Sci. 71:1472-1483.

Parris, N., L. M. Purcell, and S. M. Ptashkin. 1991. Thermal denaturation of whey proteins in skim milk. J. Agric. Food Chem. 39:2167-2170.

Patrick, P. S., and H. E. Swaisgood. 1976. Sulfhydryl and disulfide groups in skim milk as affected by direct ultra-high-temperature heating and subsequent storage. J. Dairy Sci. 59:594-600.

Prabakaran S., and S. Damodaran. 1997. Thermal unfolding of $\beta$ lactoglobulin: Characterization of initial unfolding events responsible for heat induced aggregation. J. Agric. Food Chem. 45:4303-4308.

Sfortunato, T., and W. M. Connors, inventors. 1958. Conversion of lactose to glucose and galactose with a minimum production of oligosaccharides. US Pat. No. 2,826,502.

Shimada, K., and J. C. Sheftel. 1989. Sulfhydryl group/disulfide bond interchange reactions during heat induced gelation of whey protein isolate. J. Agric. Food Chem. 37:161-168.

Taylor, M. J., and T. Richardson. 1979. Antioxidant activity of skim milk: Effect of heat and resultant sulfhydryl groups. J. Dairy Sci. 63:1783-1795.

Van Dam, B., J. G. Revallier-Warfemins, L. C. van Dam-Schermerhorn. 1950. Preparation of lactase from Saccharomyces fragilis. Neth. Milk Dairy J. 4:96.

Wendorff, W. L., C. H. Amundson, and N. F. Olson. 1970. The effect of heat treatment of milk upon the hydrolyzability of lactose by the enzyme lactase. J. Milk Food Technol. 33:377-379.

Wendorff, W. L., C. H. Amundson, N. F. Olson, and J. C. Garver. 1971. Use of yeast $\beta$-galactosidase in milk and milk products. J. Milk Food Technol. 34:294-299.

Whitaker, J. R. 1994. Principles of Enzymology for the Food Sciences, 2nd edition, Marcel Dekker, New York. 